\title{
Pattern of Living Arrangements among the Rural Elderly Muslims of West Bengal, India
}

\author{
Sk. Siraj Ali* \\ Research Investigator, Cultural Research Institute, Backward Classes Welfare Department, Government of \\ West Bengal, India. \\ *Corresponding author at: Cultural Research Institute, Backward Classes Welfare Department, Government of \\ West Bengal, Ambedkar Bhavan, P-1/4, C.I.T. Scheme No. VII(M), V.I.P. Road, P.O.-Kankurgachi, Kolkata-700 \\ 054, West Bengal, India
}

\begin{abstract}
Approaching 80 million in number, India has the second largest population of elderly people after China. The living arrangement of the elderly is seen as a parameter of great importance in understanding their difficulty in developing countries because of lack of public institutions and social security nets. Muslim people is more backward community for lack of education, economically weak, structure of household and so on the backwardness is more prone for those who are living in rural areas. There more studies article the living arrangement of elderly except Muslims. Therefore, keeping these backdrops in mind, the present research attempts to explore the present nature of living arrangement of the 200 Muslim elderly people from both sexes living in the villages. This study analyses the socio-economic, demographic, household characteristics to determine their living arrangement. The study exhibit those majorities (73.50\%) of them were living with their spouse and present sons and only $07.50 \%$ were living alone. In view of the changing socio-economic and demographic condition there is a higher proportion of elderly Muslim living alone in the future.
\end{abstract}

Keywords: Rural Elderly, Muslim, Living Arrangement, West Bengal.

\section{INTRODUCTION:}

Most elderly live in the developing World. Approaching 80 million in number, India has the second largest population of elderly people after China. Until recently, demographic research on developing countries rarely focused on this group they constitute a relatively small percentage of the total population. However, with rapid declines in fertility and mortality rates and longer life expectancies in several countries, the elderly are a growing segment of the population, and the full implications of this change have yet to be played out. The twin forces of modernization and urbanization may complicate matters further, since many of these countries are not institutionally adapted to handle the transition from traditional social support systems for the elderly to more modern ones (Treas and Logue, 1986). The most crucial aspect of living arrangements of the elderly is coresidence with adult children in extended families or multi-generational households, where kin provide income, personal care and emotional support to the elderly (Nandal 1987, Rajan and Kumar 2003). Scholars and policy makers working in this area view the living arrangements of the elderly as a measure of their wellbeing. It has been a common assumption that co-residence with children and grandchildren in multi-generational households benefit the elderly, and that the elderly who live with at least one adult child are better off and better provided for than those who live alone or with nonrelatives (Teng 2007). Thus, Cogwill (1986) concludes that coresidence of the elderly and young has been in the spirit of "life time reciprocity". Though co-residence is an important criterion for the well-being of the elderly, Chan (1997) and Irudaya Rajan et al (1999) argue that it may not always ensure a healthy relationship between successive generations and economic, emotional, and social support from the younger generation can still be provided even without co-residence. However, they believe that the level of social and economic development becomes an important determining factor. Further, it is said the co-residence does not always indicate flow of support from the younger to the older generation; coresidence may also imply child-care or help in household chores by the elderly.The Indian economy, demography and society are in a major transition. The economic development gains are not equitably shared across different geographical regions and sections of the society. These social and economic changes have brought in cultural changes as well as changes in individual characteristics. With the demographic transition under way, there are only a few children to take care of the elderly. They are now more educated, mobile, aspire for a higher standard of living and as such, changes in their individual behaviour and attitude are observed. These, in turn, are expected to bring changes in the living arrangements of the elderly with implications for their well-being. 


\section{THE ELDERLY IN INDIA:}

In India, elderly parents co-residing with their children can serve a dual purpose: children can take care of their parents' health and daily needs, while parents can provide childcare for young grandchildren. These are non-financial aspects of co residence that typify a joint living arrangement. Other benefits include those to elder health, particularly in terms of the relationship between co-residence and self-rated health, chronic and shortterm morbidity (Sudha et al. 2006). Additionally, multigenerational households allow a pooling of finances and resources. This can either relieve the household budget constraint in case of strong pension systems, or exacerbate poverty when most financial support flow is upwards. For elders that live alone, this financial safety net can disappear, adding a potential poverty dimension to ageing in India (Husain and Ghosh 2011). A longer life span of the elderly implies a longer period of dependency on children in the traditional Indian family setting, and thus higher costs to meet healthcare and other needs. In a move to alleviate the financial cost to coresidence, the Indian Government introduced the National Policy on Older Persons in 1999. This policy has provisions for tax relief or children who co-reside with their parents, allowing rebates for medical expenses and giving preference in the allotment of houses (MOSJE 1999). This policy however, is yet to be adopted and enforced by a majority of states, the locus of such policy execution in India. There is limited evidence emerging from India on the topic of living and care giving arrangements. What does exist is largely localized to a region (Panigrahi 2009; Sudha et al. 2006), or a pilot covering two states each in the north and south (Longitudinal Aging Study in India)- which are important contributions. The dataset we employ however covers seven states spread through all the regions in the country, as we will discuss in the next section. Panigrahi (2009) finds that in Orissa, the proportion of elderly living alone is on the rise. Mediating factors that reduce the likelihood of living alone include having a son and being financially dependent, while higher education increases the likelihood of living alone. Using National Family Health Survey (NFHS) data waves from 1992-93 and 200506; Sathyanarayana et al. (2012) show the change in structure of living arrangements in India. They find that about three-fourths of elderly co-reside either with their spouse and/or children and grandchildren (Sathyanarayana et al. 2012). Remarkably, in the short inter-survey period, the proportion of elders living alone or only with their spouse (thus independently of their children) increased from nine to nineteen percent. There are emergent trends from the literature that warrant attention. First, that the proportion of widows has increased compared to widowers. Second, the elderly that are most vulnerable come from the two lower wealth quintiles. Finally, the intensity of elderly living alone is evident in rural as well as urban India, rather than being just an urban phenomenon. While the NFHS is helpful in setting the stage of the magnitude of the changing living arrangements, it does not adequately answer why these changes are taking place, and the implications for elders. The novel dataset we use specifically asks such questions to elders themselves, which has not been done in the Indian setting before in such depth. Understanding the composition of households and living arrangements will help formulate evidence-based policies that will help plan for a burgeoning elder population in India

\section{RESEARCH ON LIVING ARRANGEMENTS:}

Till recent past, living arrangements for elderly in India, like other developing countries, was not an issue, as India was predominated by traditional agrarian society. Around 70 percent of its population lived in rural areas and depends upon agricultural and allied works for their livelihood. Filial roles and responsibilities are strong in Indian society. Extended family is 5 prevalent, particularly in rural India, which is viewed as the only social institution which provides care and support to its members including elderly persons. In India very little attention, compared to western industrialized countries, has been paid to develop social security, pension and public health systems to provide care and support for elderly population. In the absence of such social security schemes, elderly are dependent on their children and other family members. About 80 percent of India's working population is in informal and private sector, who are not covered under any superannuation pension scheme. People in their old age require social, economic and physical assistance, for that they tend to rely heavily on their family and persons living in their close proximity for their wellbeing and survival (Bongaarts, 2001). Studies show that (Thortton et al. 1984; Becker, 1991; Kuznets, 1978) the households throughout the developing world represent as a principal institution responsible for exchanging and distributing of goods and services between generation, and they are the venues where the cultural norms, roles and responsibilities of age and kinship are expressed. Living arrangement is viewed as a best indicator to understand the status and the wellbeing of the elderly in the society. The study conducted by Palloni (2001) indicates that the living arrangement refers to the familial system. The concept of the living arrangement is usually explained in terms of the type of family in which the elderly live, the headship they enjoy, the place they stay in and the people they stay with, the kind of relationship they maintain with their kith and kin, and on the whole, the extent to which they adjust to the changing environment (Irudaya Rajan et al. 1995). To know the determinants of the living arrangement many studies have been conducted which indicate that living arrangements are influenced by financial status, family size and structure, kinship pattern of the society, location of household, availability of 
services and the physical and mental wellbeing of the elderly (Van Solinge, 1994; Vekoff, 2001; Kan et al., 2000; Schafer, 1999). In another study done by Chen (1998) indicates that attitudes towards and perceptions about the living place are other important criteria that decide where they should live. The understanding and commitment between parents and children is one of the factors appears to have remained unchanged, particularly in rural India (Sekher, 2005). It is observed that in many cases the likelihood of co-residence of elderly mainly depends on the number of surviving children. It particularly suggest that elderly persons with large 6 number of surviving children are more likely to co-reside and less likely to live alone (Kramarow 1995; Wolf 1990; Yount 2005). Many researchers further made efforts to look into the gender preferences to co-reside which may affect the living arrangements of older persons. Differences in preferences to co-reside vary from country to country. In some countries where patrilinial system prevails, elderly prefers to co-reside with son, and are taken care by the daughter-in-laws (Ahn et al., 1997; Ofstedal et al., 1999; Aykan and Wolf, 2000; Ogawa and Retherford, 1997; Mason, 1992; Yount 2005; Shah et al., 2002). In other countries like Indonesia, coresidence with daughter is more widespread (Cameron, 2000). Another important factor which influences the choice of living arrangement among elderly is socio-economic conditions. A study conducted by Da Vanzo and Chan (1994) reveals that income is positively related to the concept of living alone in most of the developed countries. In contrast most of the countries in the developing world by cultural norms regarding family roles and filial responsibilities co-residence are prevalent. The elderly who have income from various sources such as personal savings, rent from property, government pensions etc. are more likely to co-reside with the adult children. It is observed that co-residence of elderly with offspring is prevalent in the least developed countries. In a study by Asis et al. (1995) found that co-residence and socio-economic developments are inversely related. Other studies show that parents and children are bounded to co-reside due to higher housing costs in urban areas, by residing together they share these cost (Da Vanzo and Chan, 1994; Yount, 2005). Often there is an assumption that the parent-offspring co-residence is basically to provide care and support to the elderly parents. The economic productivity and physical strength of aged persons decline with advancing years, hence they require depending on other family members. But experiences shows that, co-residence is typically mutually beneficial to both the generations. The support does not always flow in the same direction which is mostly from younger to older generation. Co-residence may also be benefited by the contributions rendered by older person such as the provision of child-care, household chores by the elderly (Da Vanzo and Chan, 1994; Chan, 1997; Irudaya Rajan et al. 1999; Hashimoto 1991). Family is viewed as the main source of care and support for elderly wellbeing. Though the care and support are two different dimensions Support broadly can be defined as financial assistance, whereas care is defined as emotional support. The financial support could be 7 provided by the state and other private institutions, but the emotional support can only be provided by the family members, relatives and cohabitant of the elderly. Family is often a significant source of care and support for older persons in courtiers where social security and social services are absent or negligible. Elderly in these situations are largely relying on the family members as their economic productivity and physical strength decline with advancing years. Thus, living arrangement becomes an important constituent of the overall well-being of the elderly and provides some indication of the level of actual support available to them (Irudaya Rajan, 2003).

\section{CONTEXT OF THE PRESENT STUDY:}

From the above discussion author may state that in India there are a good number of excellent studies on the various aspects of the elderly in both rural and urban areas. However, such type of studies relating to living arrangements of Muslims elderly living in the household located either in urban or rural areas of the country are very little of absent. Keeping this lacuna in mind, the present study aims to explore the pattern of living arrangements for the same of a particular minority community in a particular area. The authors claim that this type of unique empirical study would provide some light and ideas about the living arrangements of elderly Muslims.

\section{OBJECTIVES OF THE STUDY:}

In view of the above situation the present researcher is intended to carry out the living arrangements among the rural elderly Muslims of particular district of West Bengal with the objectives are as follows:

- To examine the socio-economic and demographic characteristics of the study population.

- To examine the pattern of living arrangements of rural elderly Muslims.

\section{STUDY AREA:}

The present study was undertaken in Nandigram I Community Development Block under Haldia Sub Division of the district of Purba Medinipur of West Bengal. These Block located in approximately $132 \mathrm{~km}$ from Kolkata, capital of West Bengal and $46 \mathrm{~km}$ from Tamluk, district head quarter of the Purba Medinipur district. Nandigram I Community Development Block is bounded by Haldia Community Development Block, across the Haldi in the north, Kakdwip and Sagar Community Development Blocks, both in South 24 Parganas district, 
across the Hooghly estuary, in the east, Khejuri I and Khejuri II Community Development Blocks in the south and Nandigram II Community Development Block in the west.

\section{MATERIALS AND METHODS:}

For the purpose of the study the present researcher will select 10 villages randomly (simple random sampling without replacement) from Nandigram I Community Development Block of Purba Medinipur district of West Bengal. From each selected village the researcher will again select 10 male Muslims of age 60 years \& above from the list of all Muslims of 60 year and more age given the latest voter list of the respective villages /booth published by the Election Commission of India. Similarly present researcher will select 10 female Muslims of age $60 \&$ more randomly from the list of female Muslims of age 60 tears \& more given in the Voter List. Data will be collected from those who will give information voluntarily. However, researcher will try to convince all the selected individuals to give the information. The present researcher may have to take substitution for few them not exceeding 10 in total.

The data will be collected on the basis of the printed structured questionnaire schedule containing the questions on socio-economic and demography as well as living arrangements. However, other standard anthropological methods like census survey, participation observation method, questionnaire method, focus group discussion, panel interview, case history method etc.

\section{RESULT AND DISCUSSION:}

Table 01 exhibits the age-sex wise distribution of the respondents under study. From the table it is revealed that out of the total number of respondents under study 100 are male and 100 are female. It is evident that out of the total number of respondent across both the sexes, $28 \%$ belong to the $60-64$ years age group; $34 \%$ in the 65-69 years age group; $23.5 \%$ in the 70-74 years age group; $10.5 \%$ belong to the $75-79$ years age group and only $4 \%$ in the age group of 80 years and above.

The table under discussion further reflects that in the age group 60-64, there are respectively $11.5 \%$ male and $16.5 \%$ female out of the total number of inmates under study. Similarly, in the age group 65-69 years there are respectively $19.5 \%$ male and $14.5 \%$ are female; in the age group $70-74$ years there are respectively $12 \%$ male and $11.5 \%$ female; in the age group 75-79 years there are respectively $5 \%$ male and $5.5 \%$ female and in the age group 80 years and above male and female respondents constitute only $2 \%$ each respectively.

Table 02 shows the marital status of the respondents based on their age group. From the table it is revealed that among the total number of respondents belong to the age group 60-64 years, 14.5\% are married; $11.5 \%$ are widow and only $2 \%$ are widower. Similarly, in the age group 65-69 years there are $22.5 \%$ married, $5 \%$ widow and $6.5 \%$ are widower; in the age group $70-74$ years $15.5 \%$ are married, $7 \%$ widow and only $1 \%$ are widower; in the age group 75-79 years $5.5 \%$ are married, $4.5 \%$ widow and only $0.5 \%$ are widower; in the age group 80 years and above $2 \%$ are married and another $2 \%$ are widow.

Table $\mathbf{0 3}$ exhibits the educational standard of the male and female respondents respectively. While dealing with the educational status of all the respondents across both the sexes under study the present researcher has considered the table simultaneously for the purpose of analysis in this regard. Thus, it is seen that out of the total number of respondents across both the sexes $23 \%$ are non-literate and $77 \%$ are literate.

It is evident from the table that under the category of non-literate there are $9.00 \%$ male and $14.00 \%$ female. The present scholar has divided all the literate respondents in different category which are namely: ability to sign, I-IV class, V-X class, Higher Secondary and above. It is evident from the table that out of the total number of respondents under the category of ability to sign $15 \%$ are male and $16 \%$ are female. It is also revealed from the table that out of the total number of respondents under the category of I-IV class standard of literacy $11 \%$ are male and $19.5 \%$ are female. It is also found that out of the total number of respondents under the category of $V$-X class standard of literacy, $10 \%$ are male and only $0.5 \%$ are female. From the table under discussion it is also revealed that out of the total number of respondents under the category of Higher Secondary and above standard 5\% are male and there is not a single female respondent.

Table 04 exhibits family type wise distribution of the respondents under study. From the table it is revealed that out of the total number of respondents across both the sexes covered in the present study $13.5 \%$ respondents used to live in nuclear family, $78.5 \%$ in joint family and remaining $8 \%$ are under the category of miscellaneous type of family which includes broken family and/or the family of accretion.

From the table it also revealed that among the total number of male respondents $8 \%$ used to live in nuclear family, $38 \%$ in joint family and $4 \%$ in broken family and/or the family of accretion. Similarly, it is found that among the total number of female respondents $5.5 \%$ used to live in nuclear family, $40.5 \%$ in joint family and only $4 \%$ in broken family and/or the family of accretion.

Table 05 exhibits the working status based distribution of the respondents. It is evident that out of the total number of respondents across both the sexes respectively $19 \%$ are workers, $50.50 \%$ are marginal workers and $30.50 \%$ are non-workers. 
From the table it also revealed that among the total number of male respondents $11.5 \%$ are worker, $27 \%$ are marginal worker and $11.5 \%$ are non-worker respectively. On the other hand, among the total number of female respectively $7.5 \%$ are worker, 23.55 are marginal worker and 19\% are non-worker. So, the table shows that there is more number of female as non-worker than their male counterpart.

Table 06 shows the monthly family income wise distribution of the respondents. It is revealed from this table that out of the total respondents across both the sexes $20 \%$ live in such families whose monthly income are Rs. 2000/- or below. Whereas, $14.5 \%$ respondents' monthly family income ranges between Rs. 2001/- to Rs. 3000/-, monthly income of 29.5\% respondents ranges between Rs. 3001/- to Rs. 4000/-, 14\% ranges between Rs. 4001 to Rs. 5000/- and 22\% respondents' monthly family income are above Rs. 5000/-.

The table further exhibits that $9.5 \%$ of the total number of male respondents live in the families having monthly income Rupees Rs. 2000/- or below, 5.5\% respondents' monthly family income ranges between Rs. 2001/- to Rs. 3000/-, monthly income of 16\% respondents ranges between Rs. 3001/- to Rs. 4000/-, 7.5\% ranges between Rs. 4001 to Rs. 5000/- and 11.5\% respondents' monthly family income are above Rs. 5000/-.

Similarly, $10.5 \%$ of the total number of female respondents live in the families having income of Rs.2001/-or below, 9\% respondents' monthly family income ranges between Rs. 2001/- to Rs. 3000/-, monthly income of $13.5 \%$ respondents ranges between Rs. 3001/- to Rs. 4000/-, 6.5\% ranges between Rs. 4001 to Rs. 5000/- and 10.5\% respondents' monthly family income are above Rs. 5000/-.

Table 07 exhibits the living arrangements based distribution of the respondents under study. It is revealed from the table that among the total number of respondents across both the sexes $7.5 \%$ are living alone; $42.50 \%$ are living with their sons; $9 \%$ are living with their married or un-married daughter; $31 \%$ are living with their spouse; $3.5 \%$ are living with their other relatives, whereas; $6.5 \%$ of the total number of respondent across both the sexes are not related to family.

From the table it appears that out of the total male respondents respectively $2.5 \%$ used to live alone, $21 \%$ are living with their sons, $4 \%$ are living with their married or un-married daughter, $20.5 \%$ are living with spouse, $2 \%$ are living with other relatives. Similarly, among the total number of females respectively, $5 \%$ used to live alone, $21.5 \%$ are living with their sons, $5 \%$ are living with their married or un-married daughter, $10.5 \%$ are living with spouse, $1.5 \%$ are living with other relatives and $6.5 \%$ respondents are not related to any family.

Table 08 exhibits the mobility status of the respondents under study. Among the total number of respondents across both the sexes $7 \%$ are bed ridden, $20.5 \%$ are slightly mobile, $42 \%$ are fairly mobile, $27 \%$ can move with the help of walking stick, $3.5 \%$ can move with the help of wheel chair.

It if further revealed that among the total number of bed ridden respondents $3 \%$ are male and $4 \%$ are female. The total number of slightly mobile respondents $6.5 \%$ are male and $14 \%$ are female. Whereas, among the total number of fairly mobile respondents $26 \%$ are male and $16 \%$ are female. Similarly, among the total number of respondents having ability to move with the help of walking stick $12.5 \%$ are male and $14.5 \%$ are female. The total number of respondents able to move with the help of wheel chair $2 \%$ are male and $1.5 \%$ are female respectively. Hence, it is concluded that there is a more number of females who are bed ridden $(4 \%)$, slightly mobile (14\%) and mobility with a stick (14.5\%) than their male counterparts respectively $(3 \%$; $6.5 \%$ and $12.5 \%$ ).

Table No. 01Age-sex Composition of the Elderly Respondents

\begin{tabular}{|l|l|l|l|l|l|l|}
\hline \multirow{2}{*}{ Age Group } & \multicolumn{2}{l}{ Male } & \multicolumn{2}{l|}{ Female } & \multicolumn{2}{l|}{ Total } \\
\cline { 2 - 7 } & $\mathbf{N}$ & $\mathbf{\%}$ & $\mathbf{N}$ & $\mathbf{\%}$ & $\mathbf{N}$ & \% \\
\hline $60-64$ & 23 & 11.50 & 33 & 16.50 & 56 & 28.00 \\
\hline $65-69$ & 39 & 19.50 & 29 & 14.50 & 68 & 34.00 \\
\hline $70-74$ & 24 & 12.00 & 23 & 11.50 & 47 & 23.50 \\
\hline $75-79$ & 10 & 05.00 & 11 & 05.50 & 21 & 10.50 \\
\hline 80 and Above & 04 & 02.00 & 04 & 02.00 & 08 & 04.00 \\
\hline Total & $\mathbf{1 0 0}$ & $\mathbf{5 0 . 0 0}$ & $\mathbf{1 0 0}$ & $\mathbf{5 0 . 0 0}$ & $\mathbf{2 0 0}$ & $\mathbf{1 0 0 . 0 0}$ \\
\hline
\end{tabular}

Table No. 02Marital Status and Age Group wise Distribution of the Respondents

\begin{tabular}{|l|l|l|l|l|l|l|l|l|}
\hline \multirow{2}{*}{ Age Group } & \multicolumn{2}{l}{ Married } & \multicolumn{2}{l|}{ Widow } & \multicolumn{2}{l|}{ Widower } & \multicolumn{2}{l|}{ Total } \\
\cline { 2 - 10 } & $\mathbf{N}$ & $\mathbf{\%}$ & $\mathbf{N}$ & $\mathbf{\%}$ & $\mathbf{N}$ & $\mathbf{\%}$ & $\mathbf{N}$ & $\mathbf{\%}$ \\
\hline $60-64$ & 29 & 14.50 & 23 & 11.50 & 04 & 02.00 & 56 & 28.00 \\
\hline $65-69$ & 45 & 22.50 & 10 & 05.00 & 13 & 06.50 & 68 & 34.00 \\
\hline $70-74$ & 31 & 15.50 & 14 & 07.00 & 02 & 01.00 & 47 & 23.50 \\
\hline
\end{tabular}


Pattern of Living Arrangements among the Rural Elderly Muslims of West Bengal, India

\begin{tabular}{|l|l|l|l|l|l|l|l|l|}
$75-79$ & 11 & 05.50 & 09 & 04.50 & 01 & 0.50 & 21 & 10.50 \\
\hline 80 and Above & 04 & 02.00 & 04 & 02.00 & 0 & 0.00 & 08 & 04.00 \\
\hline Total & $\mathbf{1 2 0}$ & $\mathbf{6 0 . 0 0}$ & $\mathbf{6 0}$ & $\mathbf{3 0 . 0 0}$ & $\mathbf{2 0}$ & $\mathbf{1 0 . 0 0}$ & $\mathbf{2 0 0}$ & $\mathbf{1 0 0 . 0 0}$ \\
\hline
\end{tabular}

Table No. 03Educational Standard wise Distribution of the Respondents

\begin{tabular}{|l|l|l|l|l|l|l|}
\hline \multirow{2}{*}{ Educational standard } & \multicolumn{2}{l}{ Male } & \multicolumn{2}{l|}{ Female } & \multicolumn{2}{l|}{ Total } \\
\cline { 2 - 8 } & $\mathbf{N}$ & $\mathbf{\%}$ & $\mathbf{N}$ & $\mathbf{\%}$ & $\mathbf{N}$ & $\mathbf{\%}$ \\
\hline Non-literate & 18 & 09.00 & 28 & 14.00 & 46 & 23.00 \\
\hline Ability to sign & 30 & 15.00 & 32 & 16.00 & 62 & 31.00 \\
\hline I - IV & 22 & 11.00 & 39 & 19.50 & 61 & 30.50 \\
\hline V - X & 20 & 10.00 & 01 & 0.50 & 21 & 10.50 \\
\hline $\begin{array}{l}\text { Higher Secondary and } \\
\text { above }\end{array}$ & 10 & 05.00 & 0 & 0.00 & 10 & 05.00 \\
\hline Total & $\mathbf{1 0 0}$ & $\mathbf{5 0 . 0 0}$ & $\mathbf{1 0 0}$ & $\mathbf{5 0 . 0 0}$ & $\mathbf{2 0 0}$ & $\mathbf{1 0 0 . 0 0}$ \\
\hline
\end{tabular}

Table No. 04Family type wise Distribution of the Respondents

\begin{tabular}{|l|l|l|l|l|l|l|}
\hline \multirow{2}{*}{ Family type } & \multicolumn{2}{|l|}{ Male } & \multicolumn{2}{l|}{ Female } & \multicolumn{2}{l|}{ Total } \\
\cline { 2 - 7 } & $\mathbf{N}$ & $\mathbf{\%}$ & $\mathbf{N}$ & $\mathbf{\%}$ & $\mathbf{N}$ & $\mathbf{\%}$ \\
\hline Nuclear Family & 16 & 08.00 & 11 & 05.50 & 27 & 13.50 \\
\hline $\begin{array}{l}\text { Joint } \\
\text { Family }\end{array}$ & 76 & 38.00 & 81 & 40.50 & 157 & 78.50 \\
\hline Miscellaneous types & 08 & 04.00 & 08 & 04.00 & 16 & 08.00 \\
\hline Total & $\mathbf{1 0 0}$ & $\mathbf{5 0 . 0 0}$ & $\mathbf{1 0 0}$ & $\mathbf{5 0 . 0 0}$ & $\mathbf{2 0 0}$ & $\mathbf{1 0 0 . 0 0}$ \\
\hline
\end{tabular}

Table No. 05Working status wise Distribution of the Respondents

\begin{tabular}{|l|l|l|l|l|l|l|}
\hline \multirow{2}{*}{ Working Status } & \multicolumn{3}{|l}{ Male } & \multicolumn{2}{l|}{ Female } & \multicolumn{2}{l|}{ Total } \\
\cline { 2 - 7 } & $\mathbf{N}$ & $\mathbf{\%}$ & $\mathbf{N}$ & $\mathbf{\%}$ & $\mathbf{N}$ & \% \\
\hline Worker & 23 & 11.50 & 15 & 07.50 & 38 & 19.00 \\
\hline Marginal Worker & 54 & 27.00 & 47 & 23.50 & 101 & 50.50 \\
\hline Non-Worker & 23 & 11.50 & 38 & 19.00 & 61 & 30.50 \\
\hline Total & $\mathbf{1 0 0}$ & $\mathbf{5 0 . 0 0}$ & $\mathbf{1 0 0}$ & $\mathbf{5 0 . 0 0}$ & $\mathbf{2 0 0}$ & $\mathbf{1 0 0 . 0 0}$ \\
\hline
\end{tabular}

Table No. 06Monthly Family Income wise Distribution of the Respondents

\begin{tabular}{|l|l|l|l|l|l|l|}
\hline \multirow{2}{*}{ Monthly Family Income } & \multicolumn{3}{|l|}{ Male } & \multicolumn{2}{l}{ Female } & \multicolumn{2}{l|}{ Total } \\
\cline { 2 - 7 } & $\mathbf{N}$ & $\mathbf{\%}$ & $\mathbf{N}$ & $\mathbf{\%}$ & $\mathbf{N}$ & \% \\
\hline Rs. $<2000$ & 19 & 09.50 & 21 & 10.50 & 40 & 20.00 \\
\hline Rs. $2001-3000$ & 11 & 05.50 & 18 & 09.00 & 29 & 14.50 \\
\hline Rs. $3001-4000$ & 32 & 16.00 & 27 & 13.50 & 59 & 29.50 \\
\hline Rs. $4001-5000$ & 15 & 07.50 & 13 & 06.50 & 28 & 14.00 \\
\hline Rs. $>5000$ & 23 & 11.50 & 21 & 10.50 & 44 & 22.00 \\
\hline Total & $\mathbf{1 0 0}$ & $\mathbf{5 0 . 0 0}$ & $\mathbf{1 0 0}$ & $\mathbf{5 0 . 0 0}$ & $\mathbf{2 0 0}$ & $\mathbf{1 0 0 . 0 0}$ \\
\hline
\end{tabular}


Table No. 07Living Arrangements wise Distribution of the Respondents

\begin{tabular}{|l|l|l|l|l|l|l|}
\hline \multirow{2}{*}{ Living arrangements } & \multicolumn{2}{l}{ Male } & \multicolumn{2}{l|}{ Female } & \multicolumn{2}{l|}{ Total } \\
\cline { 2 - 8 } & $\mathbf{N}$ & $\mathbf{\%}$ & $\mathbf{N}$ & $\mathbf{\%}$ & $\mathbf{N}$ & $\%$ \\
\hline Living alone & 05 & 02.50 & 10 & 05.00 & 15 & 07.50 \\
\hline Sons & 42 & 21.00 & 43 & 21.50 & 85 & 42.50 \\
\hline $\begin{array}{l}\text { Married or un-married } \\
\text { daughter }\end{array}$ & 08 & 04.00 & 10 & 05.00 & 18 & 09.00 \\
\hline Spouse & 41 & 20.50 & 21 & 10.50 & 62 & 31.00 \\
\hline Other relatives related to & 04 & 02.00 & 03 & 01.50 & 07 & 03.50 \\
\hline $\begin{array}{l}\text { Family not } \\
\text { respondent }\end{array}$ & 0 & 0.00 & 13 & 06.50 & 13 & 06.50 \\
\hline Total & $\mathbf{1 0 0}$ & $\mathbf{5 0 . 0 0}$ & $\mathbf{1 0 0}$ & $\mathbf{5 0 . 0 0}$ & $\mathbf{2 0 0}$ & $\mathbf{1 0 0 . 0 0}$ \\
\hline
\end{tabular}

Table No. 08Mobility of the Respondents across the Sex

\begin{tabular}{|l|l|l|l|l|l|l|}
\hline \multirow{2}{*}{$\begin{array}{l}\text { Mobility of the } \\
\text { Respondents }\end{array}$} & Male & \multicolumn{2}{l|}{ Female } & \multicolumn{2}{l|}{ Total } \\
\cline { 2 - 8 } & $\mathbf{N}$ & $\mathbf{\%}$ & $\mathbf{N}$ & $\mathbf{\%}$ & $\mathbf{N}$ & $\mathbf{\%}$ \\
\hline Bed Ridden & 06 & 03.00 & 08 & 04.00 & 14 & 07.00 \\
\hline Slightly mobile & 13 & 06.50 & 28 & 14.00 & 41 & 20.50 \\
\hline Fairly mobile & 52 & 26.00 & 32 & 16.00 & 84 & 42.00 \\
\hline Mobility with a stick & 25 & 12.50 & 29 & 14.50 & 54 & 27.00 \\
\hline Wheel Chair & 04 & 02.00 & 03 & 01.50 & 07 & 03.50 \\
\hline Total & $\mathbf{1 0 0}$ & $\mathbf{5 0 . 0 0}$ & $\mathbf{1 0 0}$ & $\mathbf{5 0 . 0 0}$ & $\mathbf{2 0 0}$ & $\mathbf{1 0 0 . 0 0}$ \\
\hline
\end{tabular}

\section{SUMMARY AND CONCLUSION}

In this research article author attempted to observe the socio-economic and demographic backgrounds, status of living arrangements. The findings generally suggest that majority of the respondents were ability to sing $(31 \%), 11.50 \%$ were widowed of the age group of $60-64,50.50 \%$ were marginally occupied and another $30.50 \%$ were not capable to do any kind of paid employment. Analysis on living arrangement of the elderly respondents indicates that a large amount of them were living with $73.50 \%$ and other family members or with only spouse. Therefore, co-residence with their kin group is a reliable assistance and support for the overall well-being of the aged people. When the number of helpful spouses or surviving sons increased there are appreciably fewer elderly living along because the presence of spouse or sons is an important variable that helped for co-residence. Likewise, when the number of generation increases living arrangement with kin members also increases. The respondents who were married living with spouse and other family members, whereas widowed with only surviving sons because they are the next option to staying with them after the death of spouse. The absence of spouse is the important variable for living with only sons. The study also revealed that the respondents who were unmarried and separated were compulsorily living alone. There was a little chance of the elderly living alone when they were economically independent and the partially or fully dependent were living with spouse or with sons. There was the majority of the bedridden and slightly mobile elderly were living with spouse or with sons and few of them were living alone or with others such as brothers, married daughters and brothers etc. The overall findings suggest that there is a close relationship among the living arrangements.

\section{REFERENCES}

[1] Ahn, T.S., Cuong, B. T., Goodkind, D., and Knodel, J (1997): 'Living Arrangement, Patrilinearity and sources of support among elderly Vietnamese'. Asia-Pacific Population Journal, Vol 12, pp 69-88.

[2] Asis, M M, Domingo, B D, knodel, J, and Mehta, K (1995): 'Living Arrangement in four Asian countries: A comparative perspective'. Journal of cross-Cultural Gerontology, Vol 13, pp 241-264.

[3] Aykan, H and Wolf, D A (2000): 'Traditionality, modernity and household composition: Parent-child coresidence in contemporary Turkey'. Research on Ageing, Vol 22,No 4, pp 395-422.

[4] Becker, G. S. (1991): 'A Treatise on the Family'. England Edition. Cambridge, MA: Harvard University Press. 
[5] Bongaarts, john and Zachary Zimmer (2001): 'Living Arrangement of Older Adults in the Developing World: An Analysis of DHS Household Survey'. Working Paper, No. 148. Population Research Division, Population Council.

[6] Cameron, M A (2000): 'The residency decision of elderly Indonesians: A nested logit analysis'. Demography, Vol 37, pp 17-27.

[7] Da Vanzo, J, and Chan, A (1994): 'Living Arrangement of Older Malasians: Who co-resides with their adult children?’. Demography, Vol 31, pp 95-113.

[8] Hashimoto, A (1991): 'Living arrangement of the aged in seven developing countries: a preliminary analysis'. Journal of cross-Cultural Gerontology, Vol 6, pp 395-504.

[9] Husain, Z. and S. Ghosh. 2011. "Is Health Status of Elderly Worsening in India? A Comparison of Successive Rounds of National Sample Survey Data." Journal of Biosocial Science 43(02):211.

[10] Irudaya, Rajan, S and Sanjay, Kumar (2003): 'Living Arrangement among Indian Elderly: Evidences from National Family Health Survey'. Economic and Political Weekly, Vol 38, No 1, pp 75-80.

[11] Irudaya, Rajan, S, U S Mishra and P S Sarma (1995): 'living Arrangement among the Indian Elderly', Honkong Journal of Gerontology, Vol. 9, No 2, pp 20-28.

[12] Irudaya, Rajan, S, U S Mishra and P S Sarma (1999): 'India's Elderly: Burden or Challenge?'. Sage Publications, New Delhi.

[13] Kan, K., A. Park and M. Chang (2000): 'A Dynamic Modleof Elderly Living Arrangement in Taiwan'. Paper presented at an Annual Meeting of the Population Association of America, Los Angeles, CA.

[14] Kramarow, E A (1995): 'The elderly who live alone in the United States: Historical perspective on household change'. Demography, Vol 32, pp 335-352.

[15] Kuznets, S. (1978): 'Size and age structure of family households: Exploratory comparisons'. Population and development Review 4: pp 187-223.

[16] Mason, K O (1992): 'Family change and support of the elderly in Asia: What do we know?', Asia-Pacific Population Journal, Vol 7, pp 13-32.

[17] MOSJE. $1999 . \quad$ "National Policy on Http://Socialjustice.Nic.in/Hindi/Pdf/Npopcomplete.Pdf.

[18] Ofstedal, M B, Knodal, J and Chayovan, N (1999): 'Intergenerational support and gender: A comparision of four Asian countries'. Southeast Asian Journal of Social Sceinces, Vol 27, pp 21-42.

[19] Ogawa, N and Retherford, R D (1997): 'Shifting costs for caring for the elderly back to families in Japan: Will it work?' Population and Development Review, Vol 23, No 1, pp 59-94.

[20] Palloni, A (2001): 'Living Arrangement of Older Persons'. United Nations Population Bulletin, Special Issue Nos 42/43, Department of Economic and Social Affairs, Population Division, New York.

[21] Panigrahi, A. 2009. "Determinants of Living Arrangements of Elderly in Orissa: An Analysis." ISEC Working Paper Series (228).

[22] Sathyanarayana, K.M., S. Kumar, and K.S. James. 2012. "Living Arrangements of Elderly in India: Policy and Programmatic Implications." BKPAI Working Paper, United Nations Population Fund, India 7.

[23] Schafer, R (1999): 'Determinants of Living Arrangements of the Elderly', W99-6, Joint Centre for Housing Studies, Harvard University, Cambridge.

[24] Sekher, T V (2005): 'Socio-economic Dimensions of old age security in India: With special reference to Karnataka', Journal of Social and Economic Development, Vol 7, No 1, pp 12-28.

[25] Shah, N, Yount, K M, Ahah, M A, and Meno, I (2002): 'Living arrangements of older women and men in Kuwait'. Journal of Cross-Cultural Gerontology, Vol 17, pp 37-55.

[26] Sudha, S., C. Suchindran, E.J. Mutran, S.I. Rajan, and P.S. Sarma. 2006. "Marital status, family ties, and self-rated health among elders in South India." Journal of Cross-Cultural Gerontology 21(3-4):103-120.

[27] Thornton, A., M. C. Chang and T. H. Sun (1984): 'Social and economic change, intergenerational relationship, and family formation in Taiwan', Demography vol 21 pp 475-499.

[28] Van Solige, Hanna (1994): 'Living Arrangement of non-married elderly people in the Netherland in 1990'. Ageing and Society, Vol 14, pp 219-236.

[29] Velkoff, Victoria A (2001): 'Living Arrangement and Well being of Older Population: Future Research Direction'. Population Bulletin of the United Nations, Vol 42, No 43, pp 376-385.

[30] Wolf, D A (1994): 'The elderly and their kin: patterns of availability and access'. In L G Martin, and S H Preston (eds) Demography of Aging, pp 146-194. Washigton: National Academy Press.

[31] Yount, K M (2005): 'The Patriarchal Bargain and Intergenerational Co-residence in Egypt'. The Sociological Quarterly, Vol 46, pp 139-166. 